\title{
CHEMICAL PROPERTIES OF NEEDLES AS AN INDICATOR OF NUTRIENT STATUS OF FERTILIZED CONIFEROUS STANDS
}

\author{
*Ilze Karklina ${ }^{1,2}$, Zaiga Anna Zvaigzne ${ }^{1}$, Jel̦ena Stola ${ }^{1}$ \\ 'Latvian State Forest Research Institute 'Silava', Latvia \\ ${ }^{2}$ University of Latvia, Latvia \\ *Corresponding author’s email: ilze.karklina@silava.lv
}

\begin{abstract}
Enhanced forest growth may respond to demand of woody resources and contribute to the climate change mitigation. Forest soil treatment with fertilizers, as well as drainage and thinning enhance forest growth. The analysis of needles is an established method in forest science to identify the nutrient status in the forest stand and need for forest soil enrichment with fertilizers. The aim of this research is to estimate the efficiency of forest soil enrichment with wood ash and ammonium nitrate in order to eliminate nutrient deficiency in forest stands. Forest soil was enriched with wood ash fertilizer or ammonium nitrate in 2016-2017. The current year needles were collected from fertilized and control plots, from three trees in each plot. The samples were collected in the period 2018-2019. Total nitrogen $\left(\mathrm{g} \mathrm{kg}^{-1}\right)$, calcium $\left(\mathrm{g} \mathrm{kg}^{-1}\right)$, magnesium $\left(\mathrm{g} \mathrm{kg}^{-1}\right)$, and potassium $\left(\mathrm{g} \mathrm{kg}^{-1}\right)$ were analyzed in the collected samples. The chemical properties of collected needles were compared at the individual object level to estimate the impact of fertilizer on forest stand. A statistically significant increase in the concentrations of potassium and phosphorus was detected in some plots treated with wood ash and ammonium nitrate. In addition, a correlation analysis conducted between the variables of chemical properties of needles and soil showed few significant correlations between nutrient content in needles and in soil samples.
\end{abstract}

Key words: wood ash, ammonium nitrate, nutrients, improvement of forest growth.

\section{Introduction}

Forest type and growth conditions characterize forest fertility. Forest stands on organic soils are often limited in nutrients; therefore, soil improvement with wood ash may compensate deficiency of particular elements (Jacobson, 2003). Still, the overall guidelines may not always be suitable for a particular region due to different geochemical and hydrological factors (Libiete et al., 2017), and even to a specific forest stand because of a particular nutrient availability in a stand.

In Latvia, several studies of improvement of forest growth conditions and impact of forest management practices are carried out. The studies show a positive tree growth response in stands fertilized with wood ash (Okmanis, Kalvis, \& Lazdina, 2018) and a longterm effect of initial fertilization of Norway spruce seedlings on stemwood volume (Jansons et al., 2015). Furthermore, studies focus also on environmental impacts of treatments, e.g., nutrient concentration in soil water, groundwater and surface water - after harvesting of coniferous stands (Libiete etal.,2017) and after fertilization and planting of a plantation (Bardule et al., 2018). In the context of possible fertilization induced nutrient leaching and impact on chemistry of water, it is essential to estimate the nutrient status of forest stands. Chemical analyses of needles or leaves alongside with analyses of soil chemistry and visual estimation of canopy vitality are commonly used methods for the diagnosis of the nutrition status of a forest stand (Mandre, 2006). Current year needles are considered to be the main indicator of nutrition status, but chemical properties of previous year needles may also be useful for evaluation (Rautio et al., 2017).
Nutrient availability in the soil of particular stand also has an impact on chemical properties of needles as an indicator of nutrient status (Saarsalmi \& Mälkönen, 2001). Analysis of soil is also advisable for estimation of nutrient availability in a forest stand. Furthermore, it is suggested that nutrient content in soil is sitespecific rather than dependent on a treatment, e.g., harvesting (Lībiete et al., 2019).

The forest soil fertilization can compensate the nutrient deficiency in forest stand, thus improving growth conditions of trees. Wood ash application generally increases $\mathrm{pH}$ and $\mathrm{Ca}$ and $\mathrm{Mg}$ concentration in forest floor (Ozolincius et al., 2006), but higher experimental doses reduce moss layer (Ozolincius, Buozyte, \& Varnagiryte-Kabasinskiene, 2007).

The chemical parameters of ash, especially the content of trace metals, as an impact of the combustion process on properties of wood have been a topic of interest in studies (Pitman, 2006). Moreover, the mobility and bioavailability (Vincevica-Gaile et al., 2019) of nutrients released with wood ash fertilization are relevant topics of studies.

In the scope of bio-economy and efforts to minimize the waste disposal in landfills, the usage of wood ash as a forest soil fertilizer to compensate the nutrient deficiency could be a rational decision. According to The Regulation of the Cabinet of Ministers, No. 506 (Cabinet of Ministers of Latvia, 2015) wood ash can be classified as 'other liming materials' if the minimal neutralizing capacity as $\mathrm{CaCO}_{3}$ equivalent is at least $20 \%$ of dry mass. State Plant Protection Service can cancel the status of waste if the wood ash material produced by a particular plant can fulfill the requirements stated by The Regulations No. 506 . 
The aim of the research was to evaluate the impact of forest soil improvement with fertilizers on tree nutrient status by estimating the changes of element concentrations in needles.

\section{Materials and Methods}

Study sites and treatment

In total, 18 experimental sites were established in coniferous forest stands managed by Joint Stock Company 'Latvia's State Forests' and the Research forest station (Table 1). The experimental sites are divided in two groups with different treatment, namely, forest stands treated with wood ash and forest stands first treated with wood ash and next with ammonium nitrate. Each of the research objects has at least one control plot and one fertilized plot to evaluate the impact of forest soil treatment at the individual research object level. The study was conducted in 36 to 94 years old Scots pine (Pinus sylvestris L.) and Norway spruce (Picea abies (L.) H.Karst.) stands, including different forest site types.

\section{Description and treatment of experimental sites}

\begin{tabular}{|c|c|c|c|c|c|}
\hline Forest site type & $\begin{array}{l}\text { Dominant tree } \\
\text { species }\end{array}$ & $\begin{array}{l}\text { Age } \\
\text { of } \\
\text { stand }\end{array}$ & $\begin{array}{l}\text { Dose: } \mathrm{t} \text { WA or } \\
\quad \mathrm{N} \mathrm{ha}\end{array}$ & $\begin{array}{l}\text { Fertilizer } \\
\text { spreading }\end{array}$ & Date of treatment \\
\hline \multicolumn{6}{|c|}{ wood ash treatment } \\
\hline Hylocomiosa/dry mineral soil & Norway spruce & 54 & $2 \mathrm{tWA}$ & manually & 11.2014 \\
\hline Hylocomiosa/dry mineral soil & Norway spruce & 54 & $2 \mathrm{tWA}$ & manually & 11.2014 \\
\hline Hylocomiosa/dry mineral soil & Norway spruce & 50 & $2 \mathrm{tWA}$ & mechanically & 05.2017 \\
\hline Myrtillosa mel./ drained mineral & Norway spruce & 53 & $3 \mathrm{tWA}$ & mechanically & 10.2016 \\
\hline Myrtillosa mel./ drained mineral soil & Norway spruce & 44 & $3 \mathrm{t}$ WA & mechanically & 05.2017 \\
\hline Myrtillosa mel./ drained mineral soil & Norway spruce & 45 & $6 \mathrm{t}$ WA & manually & 12.2016 \\
\hline Myrtillosa turf. mel./ drained organic soil & Norway spruce & 48 & $* 4$ and $8 \mathrm{t} \mathrm{WA}$ & manually & 12.2016 \\
\hline Myrtillosa turf. mel./ drained organic soil & Scots pine & 94 & $3 \mathrm{t}$ WA & mechanically & 02.2018 \\
\hline Oxalidosa turf. mel./ drained organic soil & Norway spruce & 54 & $2 \mathrm{tWA}$ & manually & 11.2014 \\
\hline Oxalidosa turf. mel./ drained organic soil & Norway spruce & 49 & $2 \mathrm{t}$ WA & manually & 11.2014 \\
\hline \multicolumn{6}{|c|}{ wood ash and ammonium nitrate treatment } \\
\hline Vacciniosa mel./ drained mineral soil & Scots pine & 66 & $\begin{array}{l}3 \mathrm{t} \mathrm{WA}+ \\
0.44 \mathrm{t} \mathrm{N}\end{array}$ & mechanically & $02.2017 / 07.2017$ \\
\hline Vacciniosa mel./ drained mineral soil & Scots pine & 65 & $\begin{array}{l}3 \mathrm{t} \mathrm{WA}+ \\
0.44 \mathrm{t} \mathrm{N}\end{array}$ & mechanically & $02.2017 / 07.2017$ \\
\hline Vacciniosa turf. mel./ drained organic soil & Scots pine & 59 & $\begin{array}{l}3 \mathrm{t} \mathrm{WA}+ \\
0.44 \mathrm{t} \mathrm{N}\end{array}$ & mechanically & $02.2017 / 07.2017$ \\
\hline Myrtillosa mel./drained mineral soil & Norway spruce & 38 & $\begin{array}{l}3 \mathrm{t} \mathrm{WA}+ \\
0.44 \mathrm{t} \mathrm{N}\end{array}$ & mechanically & $02.2017 / 07.2017$ \\
\hline Myrtillosa mel./ drained mineral soil & Norway spruce & 36 & $\begin{array}{l}3 \mathrm{t} \mathrm{WA}+ \\
0.44 \mathrm{t} \mathrm{N}\end{array}$ & mechanically & $02.2017 / 07.2017$ \\
\hline Myrtillosa turf. mel./ drained organic soil & Norway spruce & 58 & $\begin{array}{c}3 \mathrm{t} \mathrm{WA}+ \\
0.44 \mathrm{t} \mathrm{N}\end{array}$ & mechanically & $02.2017 / 07.2017$ \\
\hline Vacciniosa turf. mel./ drained organic soil & Scots pine & 60 & $\begin{array}{l}3 \mathrm{t} \mathrm{WA}+ \\
0.44 \mathrm{t} \mathrm{N}\end{array}$ & manually & $02.2017 / 07.2017$ \\
\hline Oxalidosa turf. mel./ drained organic soil & Norway spruce & 54 & $\begin{array}{l}3 \mathrm{t} \mathrm{WA}+ \\
0.44 \mathrm{t} \mathrm{N}\end{array}$ & mechanically & $10.2016 / 07.2017$ \\
\hline
\end{tabular}

WA - wood ash

$\mathrm{N}-\mathrm{NH}_{4} \mathrm{NO}_{3}$

* $4 \mathrm{tha}^{-1}$ and $8 \mathrm{tha}^{-1}$ spread in two treatment plots 
The content of nutrients in needles of Norway spruce, \% of dry mass

\begin{tabular}{|l|l|l|l|l|l|}
\hline \multicolumn{1}{|c|}{ Nutrient } & \multicolumn{1}{c|}{ Deficiency } & \multicolumn{1}{c|}{ Low } & \multicolumn{1}{c|}{ Optimal } & \multicolumn{1}{c|}{ High } & \multicolumn{1}{c|}{ Plentiful } \\
\hline $\mathrm{Ca}$ & $<0.20$ & $0.20-0.30$ & $0.30-0.50$ & $0.50-0.80$ & $>0.80$ \\
\hline $\mathrm{Mg}$ & $<0.10$ & $0.10-0.15$ & $0.15-0.30$ & $0.30-0.40$ & $>0.40$ \\
\hline $\mathrm{K}$ & $<0.40$ & $0.40-0.60$ & $0.60-1.20$ & $1.20-1.60$ & $>1.60$ \\
\hline $\mathrm{P}$ & $<0.15$ & $0.15-0.20$ & $0.20-0.40$ & $0.40-0.50$ & $>0.50$ \\
\hline
\end{tabular}

\section{Collection and analysis of samples}

The samples of needles were collected after forest soil fertilization, in 2018-2019. Current year needles were collected from three trees at each plot, from the upper part of the canopies, or from five trees if the experimental site had only one control plot and one treated plot. In addition, soil samples were collected for the reference level before the fertilization of trial plots. Samples were taken from mineral soil level at the depths: 0-10 cm, 10-20 cm, 20-40 cm and 40-80 cm.

The needles were dried in an oven at the temperature of $70{ }^{\circ} \mathrm{C}$ and ground to a fine, homogeneous powder. The soil samples were air-dried, homogenized and sieved with $2 \mathrm{~mm}$ sieve according to standard ISO 11465:1993. To determine the nutrients $\mathrm{Ca}\left(\mathrm{g} \mathrm{kg}^{-1}\right)$, $\mathrm{Mg}\left(\mathrm{g} \mathrm{kg}^{-1}\right), \mathrm{K}\left(\mathrm{g} \mathrm{kg}^{-1}\right)$ and $\mathrm{P}\left(\mathrm{g} \mathrm{kg}^{-1}\right)$, both samples were microwave digested (Mars 6 iWave, CEM) with $65 \% \mathrm{HNO}_{3}$. Needles' extracts were analyzed with Inductively Coupled Plasma Spectrophotometer (ICP-OES, iCAP 7200 Duo, Thermo Fisher Scientific) and soils extracts - with Flame Atomic Absorption Spectroscopy (FAAS, AAnalyst 200, Perkin Elmer). Statistical analysis

We used Wilcoxon rank sum test with continuity correction (non-parametric test) to estimate differences between the control and the treated plots at the individual forest stand level. To characterize the impact of nutrient status in the soil on the chemical properties of needles, a Spearman correlation analysis was conducted between the same nutrients in needles and soil samples. The tests were conducted at a 95\% confidence level, in program $\mathrm{R}$ (R Core..., 2018). In addition, the results were compared with the deficiency and optimum values of elements in needles of Norway spruce determined by Nollendorfs (2008) and used in Latvia (Table 2).

The concentration of nutrients in needles collected from Scots pine stands was compared with the optimal values (\% of dry mass) determined by Kaposts and Sacenieks (1981): Ca 0.25-0.30\%; Mg 0.09-0.10\%; K $0.50-0.60 \%$; P 0.14-0.15\%.

\section{Results and Discussion}

Differences in nutrient concentration between fertilized and control plots

The mean values of nutrient concentration in needles collected from control and fertilized plots are summarized in Table 4 and Table 5. Table 4 presents differences in chemistry of needles at the individual object level fertilized with wood ash.

At the individual research object level, there were elevated concentrations of calcium and magnesium in wood ash treated plots if compared with control plots. This tendency was observed also for potassium and phosphorus but to a lesser extent. In this trial group no statistically significant differences were detected; however, the tendency of elevated nutrient status in current year needles collected from wood ash treated plots was observed in a part of experimental objects.

If compared with the values given by Nollendorfs (2008), the calcium level in Norway spruce stands is optimal or even high without any deficiencies observed. However, the analysis of current year needles indicated low concentrations of magnesium and even deficiency of this element in particular stands. Similarly, in a part of Norway spruce stands potassium and phosphorus levels in the needles were optimal, but in several stands deficiency of these elements was detected. Still, needle nutrient level below optimal does not necessarily indicate that the tree growth is limited by this element (Jacobson, 2003).

The nutrient status in current year needles was above the optimum in the 54-years-old Scots pine stand, except for potassium. However, the concentration of potassium was optimal in wood ash fertilized plot, compared with the control plot, 'where there' was a deficiency of the element observed.

Interestingly, in the 45 and 48-years-old Norway spruce experimental objects treated with wood ash dose $6 \mathrm{tha}^{-1}$, and $4 \mathrm{t} \mathrm{ha}^{-1}$ in one trial plot and $8 \mathrm{tha}^{-1}$ in another trial plot - in the second stand, respectively, a tendency of elevated concentrations of calcium, magnesium and phosphorus were observed, although no statistically significant differences were detected. This suggests that the nutrient uptake is limited by the capacity of trees. However, doses of $6 \mathrm{t} \mathrm{ha}^{-1}$ may be recommended for plantations, where the wood ash enhances the growth of hybrid aspen (Bardule et al., 2013).

The Table 5 represents differences in chemistry of needles at the individual object level, fertilized first with wood ash and next with ammonium nitrate. 


\section{Nutrient concentrations in needles from control and wood ash treated plots} (mean values \pm standard error of the mean)

\begin{tabular}{|c|c|c|c|c|c|c|c|}
\hline Forest type & $\begin{array}{c}\text { Tree } \\
\text { species }\end{array}$ & $\begin{array}{c}\text { Stand } \\
\text { age }\end{array}$ & Plot & $\mathrm{Ca}$ & $\mathrm{Mg}$ & $\mathrm{K}$ & $\mathrm{P}$ \\
\hline \multirow{2}{*}{ Hylocomiosa/ dry mineral soil } & \multirow[t]{2}{*}{ NS } & \multirow[t]{2}{*}{54} & $\mathrm{C}$ & $4.3 \pm 1.9 \mathrm{o}$ & $1.0 \pm 0.5 \downarrow$ & $4 \pm 2 \downarrow$ & $1.5 \pm 0.7 \downarrow$ \\
\hline & & & WA & $5 \pm 20$ & $1.3 \pm 0.6 \downarrow$ & $5.2 \pm 2.3 \downarrow$ & $1.8 \pm 0.8 \downarrow$ \\
\hline \multirow{2}{*}{ Hylocomiosa/ dry mineral soil } & \multirow[t]{2}{*}{ NS } & \multirow[t]{2}{*}{54} & $\mathrm{C}$ & $6.0 \pm 0.6 \uparrow$ & $1.33 \pm 0.9 \downarrow$ & $5.2 \pm 0.7 \downarrow$ & $1.2 \pm 0.2 \downarrow$ \\
\hline & & & WA & $4.9 \pm 0.8 \mathrm{o}$ & $1.36 \pm 0.9 \downarrow$ & $5.4 \pm 0.7 \downarrow$ & $1.58 \pm 0.09 \downarrow$ \\
\hline \multirow{2}{*}{ Hylocomiosa/dry mineral soil } & \multirow[t]{2}{*}{ NS } & \multirow[t]{2}{*}{50} & $\mathrm{C}$ & $5.1 \pm 0.3 \uparrow$ & $1.41 \pm 0.05 \downarrow$ & $6.3 \pm 0.4 \mathrm{o}$ & $1.37 \pm 0.06 \downarrow$ \\
\hline & & & WA & $5.9 \pm 0.5 \uparrow$ & $1.52 \pm 0.08 \mathrm{o}$ & $6.0 \pm 0.5 \mathrm{o}$ & $1.42 \pm 0.07 \downarrow$ \\
\hline Myrtillosa mel./ drained mineral & NS & 53 & WA & $3.5 \pm 0.2 \mathrm{o}$ & $0.99 \pm 0.03 \downarrow$ & $4.3 \pm 0.2 \downarrow$ & $1.05 \pm 0.04 \downarrow$ \\
\hline \multirow{2}{*}{$\begin{array}{l}\text { Myrtillosa mel./ drained mineral } \\
\text { soil }\end{array}$} & \multirow[t]{2}{*}{ NS } & \multirow[t]{2}{*}{44} & $\mathrm{C}$ & $6.8 \pm 0.4 \uparrow$ & $1.7 \pm 0.2 \mathrm{o}$ & $6.7 \pm 0.7 \mathrm{o}$ & $1.4 \pm 0.1 \downarrow$ \\
\hline & & & WA & $7.2 \pm 0.4 \uparrow$ & $1.65 \pm 0.08 \mathrm{o}$ & $6.7 \pm 0.3 \mathrm{o}$ & $1.20 \pm 0.08 \downarrow$ \\
\hline \multirow{2}{*}{$\begin{array}{l}\text { Myrtillosa mel./ drained mineral } \\
\text { soil }\end{array}$} & \multirow[t]{2}{*}{ NS } & \multirow[t]{2}{*}{45} & $\mathrm{C}$ & $4.2 \pm 0.5 \mathrm{o}$ & $1.24 \pm 0.05 \downarrow$ & $7.2 \pm 0.4 \mathrm{o}$ & $2.2 \pm 0.1 \mathrm{o}$ \\
\hline & & & WA & $4.1 \pm 0.2 \mathrm{o}$ & $1.28 \pm 0.03 \downarrow$ & $7.7 \pm 0.8 \mathrm{o}$ & $2.1 \pm 0.1 \mathrm{o}$ \\
\hline \multirow{2}{*}{$\begin{array}{l}\text { Myrtillosa turf. mel./ drained or- } \\
\text { ganic soil }\end{array}$} & \multirow[t]{2}{*}{ NS } & \multirow[t]{2}{*}{48} & $\mathrm{C}$ & $4.3 \pm 0.2 \mathrm{o}$ & $1.19 \pm 0.05 \downarrow$ & $6.4 \pm 0.4 \mathrm{o}$ & $1.6 \pm 0.1 \downarrow$ \\
\hline & & & WA & $5.4 \pm 0.6 \uparrow$ & $1.2 \pm 0.1 \downarrow$ & $6.6 \pm 0.3 \mathrm{o}$ & $1.61 \pm 0.09 \downarrow$ \\
\hline \multirow{2}{*}{$\begin{array}{l}\text { Myrtillosa turf. mel./ drained or- } \\
\text { ganic soil }\end{array}$} & \multirow[t]{2}{*}{ SP } & \multirow[t]{2}{*}{94} & $\mathrm{C}$ & $3.9 \pm 0.7 \uparrow$ & $1.25 \pm 0.05 \uparrow$ & $4.8 \pm 0.1 \downarrow$ & $1.8 \pm 0.1 \uparrow$ \\
\hline & & & WA & $3.9 \pm 0.3 \uparrow$ & $1.26 \pm 0.04 \uparrow$ & $5.1 \pm 0.2 \mathrm{o}$ & $1.82 \pm 0.04 \uparrow$ \\
\hline \multirow{2}{*}{$\begin{array}{l}\text { Oxalidosa turf. mel./ drained or- } \\
\text { ganic soil }\end{array}$} & \multirow[t]{2}{*}{ NS } & \multirow[t]{2}{*}{54} & $\mathrm{C}$ & $7.9 \pm 0.6 \uparrow$ & $1.39 \pm 0.06 \downarrow$ & $2.3 \pm 0.3 \downarrow$ & $1.33 \pm 0.09 \downarrow$ \\
\hline & & & WA & $8.6 \pm 0.7 \uparrow$ & $1.38 \pm 0.05 \downarrow$ & $2.1 \pm 0.2 \downarrow$ & $1.14 \pm 0.03 \downarrow$ \\
\hline \multirow{2}{*}{$\begin{array}{l}\text { Oxalidosa turf. mel./ drained or- } \\
\text { ganic soil }\end{array}$} & \multirow[t]{2}{*}{ NS } & \multirow[t]{2}{*}{49} & $\mathrm{C}$ & $6.1 \pm 0.7 \uparrow$ & $1.24 \pm 0.02 \downarrow$ & $2.4 \pm 0.2 \downarrow$ & $1.49 \pm 0.08 \downarrow$ \\
\hline & & & WA & $6.9 \pm 0.5 \uparrow$ & $1.1 \pm 0.1 \downarrow$ & $2.3 \pm 0.2 \downarrow$ & $1.2 \pm 0.2 \downarrow$ \\
\hline \multicolumn{8}{|l|}{$\begin{array}{l}\text { NS - Norway spruce } \\
\text { SP - Scots pine } \\
\text { C - control plot } \\
\text { WA - wood ash treated plot }\end{array}$} \\
\hline
\end{tabular}

In this experimental group, the most pronounced impact of wood ash on the chemistry of current year needles was revealed in elevated concentrations of potassium and phosphorus, if control and fertilized plots were compared. The elevated concentrations of calcium and magnesium were detected in comparatively smaller number of experimental objects. However, there was a statistically significant increase in the content of potassium and phosphorus in some of the Norway spruce and Scots pine stands, while in literature significant increase of potassium has been observed in coniferous stands on mineral soil (Jacobson, 2003).

According to the nutrient values given by Nollendorfs (2008), the calcium level is high in most Norway spruce stands, and magnesium level is determined as optimal in these objects. The chemical composition of current year needles showed diminished concentrations or even deficiency of potassium. It could be explained with antagonism between calcium and potassium (Mandre, 2006). Deficient status of phosphorus was detected in 54-years old Norway spruce stand on drained organic soil, but in the most part of Norway spruce stands the potassium content was optimal.

The detected nutrient levels in the needles are optimal or even above the optimum level in the trial objects of Scots pine. In comparison with the trial objects of Norway spruce, the concentration of calcium in needles of Scots pine was relatively lower, similarly to the 94-year-old Scots pine experimental objects treated with wood ash (Table 4).

It must be noted that part of the nutrients that were detected in needles, may have been accumulated on needle surface. The needles collected in this research were not washed with distilled water before drying. However, according to the ICP Forest Guidelines on Sampling and Analysis of Needles and Leaves (Rautio et al., 2017), only samples collected from polluted areas or from regions near the sea should be washed. Moreover, the design of this research focuses on estimation of the impact of wood ash treatment by comparing differences of control and treated plots at the individual research object. So the chemical properties were compared for the samples collected from relatively similar conditions, except for the fertilization. 


\section{Nutrient concentrations in needles from control and combined wood ash and ammonium nitrate fertilized treated plots}

\begin{tabular}{|c|c|c|c|c|c|c|c|}
\hline Forest type & $\begin{array}{c}\text { Tree } \\
\text { species }\end{array}$ & $\begin{array}{c}\text { Stand } \\
\text { age }\end{array}$ & Plot & $\mathrm{Ca}$ & $\mathrm{Mg}$ & $\mathrm{K}$ & $\mathrm{P}$ \\
\hline \multirow{2}{*}{$\begin{array}{l}\text { Vacciniosa mel./ drained } \\
\text { mineral soil }\end{array}$} & \multirow[t]{2}{*}{ SP } & \multirow[t]{2}{*}{66} & $\mathrm{C}$ & $3.7 \pm 0.4 \uparrow$ & $1.13 \pm 0.08 \uparrow$ & $* 5.8 \pm 0.10$ & $1.7 \pm 0.2 \uparrow$ \\
\hline & & & WAN & $3.0 \pm 0.3 \mathrm{o}$ & $1.07 \pm 0.06 \uparrow$ & $* 6.6 \pm 0.2 \uparrow$ & $2.28 \pm 0.09 \uparrow$ \\
\hline \multirow{2}{*}{$\begin{array}{l}\text { Vacciniosa mel./ drained } \\
\text { mineral soil }\end{array}$} & \multirow[t]{2}{*}{ SP } & \multirow[t]{2}{*}{65} & $\mathrm{C}$ & $3.4 \pm 0.1 \uparrow$ & $1.33 \pm 0.05 \uparrow$ & $5.5 \pm 0.20$ & $2.13 \pm 0.06 \uparrow$ \\
\hline & & & WAN & $3.0 \pm 0.2 \mathrm{o}$ & $1.18 \pm 0.07 \uparrow$ & $6.1 \pm 0.2 \uparrow$ & $2.30 \pm 0.08 \uparrow$ \\
\hline \multirow{2}{*}{$\begin{array}{l}\text { Vacciniosa turf. mel./ } \\
\text { drained organic soil }\end{array}$} & \multirow[t]{2}{*}{ SP } & \multirow[t]{2}{*}{59} & $\mathrm{C}$ & $2.6 \pm 0.2 \mathrm{o}$ & $1.47 \pm 0.08 \uparrow$ & $5.7 \pm 0.2 \mathrm{o}$ & $* 2.09 \pm 0.03 \uparrow$ \\
\hline & & & WAN & $2.8 \pm 0.6 \mathrm{o}$ & $1.37 \pm 0.04 \uparrow$ & $5.9 \pm 0.3 \mathrm{o}$ & $* 2.28 \pm 0.07 \uparrow$ \\
\hline \multirow{2}{*}{$\begin{array}{l}\text { Myrtillosa mel./ drained } \\
\text { mineral soil }\end{array}$} & \multirow[t]{2}{*}{ NS } & \multirow[t]{2}{*}{38} & $\mathrm{C}$ & $7.3 \pm 0.5 \uparrow$ & $1.72 \pm 0.08 \mathrm{o}$ & $3.4 \pm 0.3 \downarrow$ & $2.2 \pm 0.2 \mathrm{o}$ \\
\hline & & & WAN & $6.1 \pm 0.7 \uparrow$ & $1.6 \pm 0.10$ & $4.6 \pm 0.5 \downarrow$ & $2.2 \pm 0.1 \mathrm{o}$ \\
\hline \multirow{2}{*}{$\begin{array}{l}\text { Myrtillosa mel./drained } \\
\text { mineral soil }\end{array}$} & \multirow[t]{2}{*}{ NS } & \multirow[t]{2}{*}{36} & $\mathrm{C}$ & $6.6 \pm 0.9 \uparrow$ & $1.59 \pm 0.03 \mathrm{o}$ & $* 4.5 \pm 0.6 \downarrow$ & $* 1.95 \pm 0.07$ \\
\hline & & & WAN & $7.0 \pm 0.7 \uparrow$ & $1.52 \pm 0.07 \mathrm{o}$ & $* 5.7 \pm 0.7 \downarrow$ & $* 2.3 \pm 0.1$ \\
\hline \multirow{2}{*}{$\begin{array}{l}\text { Myrtillosa turf. mel./ } \\
\text { drained organic soil }\end{array}$} & \multirow[t]{2}{*}{ NS } & \multirow[t]{2}{*}{58} & $\mathrm{C}$ & $7.5 \pm 0.4 \uparrow$ & $1.76 \pm 0.05 \mathrm{o}$ & $2.5 \pm 0.2 \downarrow$ & $2.3 \pm 0.1 \mathrm{o}$ \\
\hline & & & WAN & $7.6 \pm 0.6 \uparrow$ & $1.65 \pm 0.07 \mathrm{o}$ & $3.2 \pm 0.3 \downarrow$ & $2.00 \pm 0.07 \mathrm{o}$ \\
\hline \multirow{2}{*}{$\begin{array}{l}\text { Vacciniosa turf. mel./ } \\
\text { drained organic soil }\end{array}$} & \multirow[t]{2}{*}{ SP } & \multirow[t]{2}{*}{60} & $\mathrm{C}$ & $3.6 \pm 0.3 \uparrow$ & $1.31 \pm 0.07 \uparrow$ & $5.5 \pm 0.1 \mathrm{o}$ & $\mathrm{NV}$ \\
\hline & & & WAN & $3.3 \pm 0.4 \uparrow$ & $1.4 \pm 0.1 \uparrow$ & $6.8 \pm 0.9 \uparrow$ & $2.2 \pm 0.3 \uparrow$ \\
\hline \multirow{2}{*}{$\begin{array}{l}\text { Oxalidosa turf. mel./ } \\
\text { drained organic soil }\end{array}$} & \multirow[t]{2}{*}{ NS } & \multirow[t]{2}{*}{54} & $\mathrm{C}$ & $4.4 \pm 0.7 \mathrm{o}$ & $0.95 \pm 0.07 \downarrow$ & $1.60 \pm 0.07 \downarrow$ & $1.30 \pm 0.05 \downarrow$ \\
\hline & & & WAN & $4.7 \pm 0.3 \mathrm{o}$ & $1.05 \pm 0.07 \downarrow$ & $1.9 \pm 0.2 \downarrow$ & $1.22 \pm 0.07 \downarrow$ \\
\hline \multicolumn{4}{|c|}{$\begin{array}{l}\text { NS - Norway spruce } \\
\text { SP - Scots pine } \\
\text { C - control plot } \\
\text { WAN - wood ash and ammonium nitrate treated plot } \\
\text { o - optimal concentration of element }\end{array}$} & \multicolumn{4}{|c|}{$\begin{array}{l}* \text { - statistically significant differences between control pl } \\
\text { and treated plot }(\mathrm{p}<0.05) \\
\uparrow-\text { concentration of element exceeds the optimum level } \\
\downarrow-\text { concentration of element is below the optimum level } \\
\mathrm{NV} \text { - no value }\end{array}$} \\
\hline
\end{tabular}

Correlation between chemical parameters of needles and soil

Only statistically significant correlations are summarized in Table 6. Correlations between nutrient concentrations in needles and soil among fertilized

Table 5 
For the most part, the calculated correlations between needle and soil properties of the trial plots are positive, although a few negative relationships are found mostly for the control plots. Considering these results, it is planned to analyze nutrient concentrations in soil and litter samples collected after forest soil treatment from both - control and fertilized plots.

\section{Conclusions}

1. There were statistically significant differences only in the concentrations of potassium and phosphorus in the samples of needles collected from the forest stands fertilized first with wood ash and next with ammonium nitrate.

2. For the most part, elevated potassium concentrations in needles were detected in comparison to the control plots, and this tendency was observed in all experimental objects of both tree species and all growth conditions. A similar tendency was detected for calcium and to a lesser extent also for magnesium and phosphorus, thereby, indicating the impact of forest soil fertilization with wood ash.

3. For the most part the nutrient content of needles was optimal or more than optimal in the experimental objects of Scots pine stands, but optimal or even high content was detected mostly for calcium and magnesium in the current year needles collected from Norway spruce stands.

4. No general pattern of nutrient concentration in the needles was detected for forest types, dominant tree species or stand age, except for calcium, which was detected in relatively higher concentrations in Norway spruce stands.

5. We found only few correlations between nutrient content in needles and in soil samples collected before the forest soil fertilization.

\section{Acknowledgements}

The study is implemented within the scope of the memorandum between the Joint Stock Company 'Latvia's State Forests' and LSFRI 'Silava' on 'Collaboration in scientific research' from October 11, 2011. The research was conducted within the scope of the Joint Stock Company 'Latvia's State Forests' research project 'Research program on forest fertilization’ (2016-2021).

\section{References}

Bardule, A., Lazdina, D., Bardulis, A., \& Sarkanabols, T. (2018). Macronutrient leaching in a fertilized juvenile hybrid aspen (Populus tremula L. $\times$ P. tremuloides Michx.) plantation cultivated in an agroforestry system in Latvia. Hydrology Research. 49(2), 407-420. DOI: 10.2166/nh.2017.054.

Bardule, A., Rancane, S., Gutmane, I., Berzins, P., Stesele, V., Lazdina, D., \& Bardulis, A. (2013). The effect of fertiliser type on hybrid aspen increment and seed yield of perennial grass cultivated in the agroforestry system. Agronomy Research. 11(1), 13-24.

Cabinet of Ministers of Latvia. (2015). Regulations Regarding the Identification, Quality Conformity Assessment and Sale of Fertilisers and Substrates. No 506. Retrieved March 13, 2020, from https://likumi.lv/ta/en/en/ $\mathrm{id} / 276480$-regulations-regarding-the-identification-quality-conformity-assessment-and-sale-of-fertilisersand-substrates.

Jacobson, S. (2003). Addition of Stabilized Wood Ashes to Swedish Coniferous Stands on Mineral Soils Effects on Stem Growth and Needle Nutrient Concentrations. Silva Fennica, 37(4), 437-450. DOI: $10.14214 /$ sf.483.

Jansons, Ā., Matisons, R., Krišāns, O., Džeriņa, B., \& Zeps, M. (2016). Effect of initial fertilization on 34-year increment and wood properties of Norway spruce in Latvia. Silva Fennica, 50 (1), 1-8. DOI: 10.14214/ sf. 1346.

Kaposts, V., \& Sacenieks, R. (1981). Mežaudžu barošanās režīms un to mēslošana (Nutritional regime and fertilization of forest stands). Riga: LatZTIZPI. (in Latvian).

Libiete, Z., Bardule, A., Klavins, I., Kalvite, Z., \& Lazdins, A. (2019). Medium-term impact of stump harvesting on general soil parameters in Hylocomiosa site type. In annual $25^{\text {th }}$ International scientific conference: Research for Rural Development 2019, 15-17 May 2019 (pp. 58-64).

Libiete, Z., Bardule, A., Murniece, S., \& Lupikis, S. (2017). Impact of clearfelling on dissolved nitrogen content in soil-, ground-, and surface waters: initial results from a study in Latvia. Agronomy Research, 15(3), $767-787$.

Mandre, M. (2006). Influence of wood ash on soil chemical composition and biochemical parameters of young Scots pine. Proc. Estonian Acad. Sci. Biol, 55(2), 91-107.

Nollendorfs, V. (2008). Eglu audžu panīkuma un sabrukšanas cēloṇu noskaidrošana, to samazināšanas iespējamie pasākumi (Identification of causes of decline and deterioration of spruce stands, possible measures to diminish those causes). Salaspils: LSFRI Silava. (in Latvian).

Okmanis, M., Kalvis, T., \& Lazdina, D. (2018). Initial evaluation of impact of evenness of spreading wood ash in forest on additional radial increment. In $17^{\text {th }}$ International Scientific Conference: Engineering for Rural 
Development, 23-25 May, 2018 (pp. 1902-1908). Jelgava, Latvia: Latvia University of Life Sciences and Technologies. DOI: 10.22616/ERDev2018.17.N491.

Ozolincius, R., Armolaitis, K., Raguotis, A., Varnagiryte, I., \& Zenkovaite, J. (2006). Influence of wood ash recycling on chemical and biological condition of forest Arenosols. Journal of Forest Science, 52(Special Issue), 79-86. DOI: 10.17221/10164-JFS.

Ozolincius, R., Buozyte, R., \& Varnagiryte-Kabasinskiene, I. (2007). Wood ash and nitrogen influence on ground vegetation cover and chemical composition. Biomass and Bioenergy, 31(10), 710-716. DOI: 10.1016/j.biombioe.2007.06.015.

Pitman, R.M. (2006). Wood ash use in forestry - a review of the environmental impacts. Forestry, 79(5), 563-588. DOI: 10.1093/forestry/cpl041.

Rautio, P., Fürst, A., Stefan, K., Raitio, H., \& Bartels, U. (2017). Part XII: Sampling and Analysis of Needles and Leaves. In: UNECE ICP Forests Programme Co-ordinating Centre (ed.): Manual on methods and criteria for harmonized sampling, assessment, monitoring and analysis of the effects of air pollution on forests. Thünen Institute of Forest Ecosystems, Eberswalde, Germany.

Saarsalmi, A., \& Mälkönen, E. (2001). Forest Fertilization Research in Finland: A Literature Review. Scandinavian Journal of Forest Research, 16(6), 514-535. DOI: 10.1080/02827580152699358.

Vincevica-Gaile, Z., Stankevica, K., Irtiseva, K., Shishkin, A., Obuka, V., Celma, S., \& Klavins, M. (2019). Granulation of fly ash and biochar with organic lake sediments - A way to sustainable utilization of waste from bioenergy production. Biomass and Bioenergy, 125, 23-33. DOI: 10.1016/j.biombioe.2019.04.004. 